\title{
FORESTRY UPDATE
}

\section{Canadian Federation of Professional Foresters Associations Meets}

The Canadian Federation of Professional Foresters Associations met in October and discussed National Codes of Practice, the creation of a mational voice for forestry, continuing education and other items. The ARPF of NB held the chair in 1992 . The CIF/IFC takes over as Chair of the CFPFA in 1993.

\section{World Wildlife Fund Report Card}

The World Wildlife Fund recently released an annual report card on government, toward the goal of setting aside $12 \%$ of Canada as wilderness. The WWF gave the Federal Government and Prince Edward Island each an $\mathrm{A}-$ the top scores. The group suggested that the protected wilderness grew from $3.4 \%$ of Canada's total area to $4.6 \%$ in the past year, and described this as modest progress. Ontario got a C + as did Quebec and the wornt mark, a D - went to New Brunswick which was described as still laying the foundations.

\section{New Quebec Pulpmill Standards}

The Quebec Government recently announced new regulations to control pollution from pulp and paper mills. The regulations came into effect October 22 and could force pulp mills to spend $\$ 1$ billion over the next six years cleaning up pollution. The regulations specify a $40 \%$ reduction in the amount of organochlorines dumped into waterways and $90 \%$ reduction in the acute toxicity of mill effluent, a $75 \%$ reduction in organic waste and a reduction in air pollution. The regulations provide for fines of $\$ \$ 00,000$ up from the present level of $\$ 30,000$.

\section{Pulpmill Effluent and Fish}

A study released by the Pulp and Paper Research Institute suggests that pulpmill effluent poses no problems to fish. Greenpeace responded predictably by suggesting that the study is flawed. The study found that within the normal range of concentrations of effluents there was no significant difference between the development of eges hatched and reared in clean water and those which spent their entire life in the treated effluents. Greenpeace suggested that the study was flawod because it did not deal with long term effects and they are concerned that organochlorines build up and move through the food chain and have an impact. The study also supports an earlier report by the Conference Board of Canada which suggests that there is no proof that eliminating chlorine will benefit the environment.

\section{Abitibi-Price Mill Purchase Plans Stalled}

Employees of the Abitibi-Price mill in Pine Falls. Manitoba were attempting to purchase the mill. The purchase plan has been stalled after the withdrawal of a potential S15 million imvestor. Mutual Life Company withdrew forcing the purchasing team to miss a September 30th deadline for arranging financing. The Employee team is trying to raise $\$ 25$ million in private sector funding. The senior management at Abitibi view the setback as temporary and appear to be willing to grant more time.

\section{New BC Forest Minister}

Art Charbonneau has been sworn in as Forest Minister to replace Dan Miller in BC. Dan Miller was suspended from his dutics due to a conflict of interest as a result of Miller's decision earlier this year to transfer a forest licence from West Shore Terminals LAd, to Repap Carnaby. At the time Miller was on a leave of absense from Skeena Cellulose a subsidiary of Repap Enterprises Inc.

\section{Industry Energy Reduction Project}

Qucbec and Ontario Paper Company announced u $\mathbf{\$ 2 0}$ million energy reduction project, which would cut electrical costs and increase the recycled content of its paper. $\$ 12$ million will be spent in switching the processing of virgin fibre to a nighttime operation from the current midday operation. This will enable them to take advantage of $30 \%$ reduction in electrical rates. An additional $\$ 8$ million will be spent to cut back on pulping of virgin fibre by $10 \%$ while increasing the processing capacity of the recycled fibre by $20 \%$. The net result will be a reduction in electrical demands of 10 megawatts per year while increasing rocycled content of newsprint from 60 is $70 \%$.

\section{Canadians Suffering Environmental Fatigue}

A recent national poll by Environies found that Canadians are suffering from a form of environmental fatigue. People generally felt satisfied with what they had done about the environment and were confused by conflicting information. The survey was done for Environment Canada in December 1991 and found that one in four Canadians put hazardous waste in their regular garbage. while few conserved water and very few wanted more parkland created.

\section{BC Pulpmill Standards Being Re-considered}

The $\mathrm{BC}$ government is said to be re-considering its decision to impose the toughest pulpmill pollution standards in the world. The government's standards amount to a ban on the use of all forms of chlorine to bleach pulp and could cost BC companies up to $\$ 900$ million to implement. Senior government officials acknowledge privately that the chlorine ban may have been good environmental politics but had no basis in science or economics. 